\title{
Motivations of Vietnamese Students in Study Abroad: A Case of Vietnamese Graduate Students in the Philippines
}

\author{
Tran Thanh Huong (Corresponding author) \\ University of Social Sciences and Humanities \\ Ho Chi Minh City, Viet Nam \\ E-mail: huongpalawan@gmail.com \\ Le Van Cong \\ University of Social Sciences and Humanities \\ Ho Chi Minh City, Viet Nam
}

Received: November 29, 2017 Accepted: December 29, 2017 Published: January 14, 2018

doi:10.5296/ire.v6i1.12245 URL: http://dx.doi.org/10.5296/ire.v6i1.12245

\begin{abstract}
This paper investigates the motivational factors of Vietnamese graduate students choose to study abroad and why they select the Philippines as their academic destination. Descriptive data using mixed method from 56 Vietnamese graduate students (VNGSs) in six universities in Metro Manila were collected through questionnaires and semi-structured interview. The findings reveal that VNGSs respectively identify "professional development", "English improvement and "better educational quality" as the most important motivational factors to study abroad. The factors of affordable tuition fees and living costs, English speaking environment, convenience for travelling and the closeness of the Philippines are considered as very significant factors influence VNGSs' coming to study in this country. From the findings, the paper discusses their implications for Vietnam graduate education.
\end{abstract}

Keywords: Vietnamese graduate student, motivation, integration, study abroad

\section{Introduction}

Education is considered as the heart of humanistic development and it is a symbol of nation's 
competitive capacity (Nelly, Karen, 2014); Evidence has proven that a person with an earned better education will have better economic opportunities, higher productivity, and healthier health (Baum \&Payea, 2005). Specifically, the statistics of OECD (2012) indicated that a person with higher education in industrialized countries earned $58 \%$ more than a counterpart with only a secondary school degree. For these reasons, education is considered as major tool influences on individual and nation's future prosperity. Nowadays, in the context of economic openness and advances in science and flow information technology, and the demands of high skilled human resources, the role of education has played greater part to both national and personal development. It challenges to education providers in providing quality services and education receivers in acquiring adequate competency to have greater opportunity to actively engage in the knowledge-bases economy. Thus, choosing the best education becomes a crucial priority of many people, and recently seeking overseas education has become popular to many students.

This tendency is brought by the effect of globalization with worldwide multi-dimensional operations, the impact of cooperation and integration at both region and international brings to the term "internationalization" which was described as "anything and everything remotely linked to worldwide, intercultural, global or international” (Knight, 2012, p22). Cross border education is part of internationalization, and it has been becoming popular phenomena even though "its form has shifted from a development cooperation framework to a partnership model and now to a commercial and competitiveness model" (Knight, 2012, p.20). The competition among educational institutions locally and globally has created the diversity of educational forms especially at international education. Beside of formal education with traditional style, the availability and accessibility of other forms of education such as distance learning, e-learning, offshore campus program, and study abroad recently have created more chance for student to pursue their study at both domestic and international programs. This reality contrasts with past perception on international education that was just happened from developing countries to developed countries, and it was only reserved for the best and the brightest students (Arthur \& Popadiuk, 2015). Nowadays, the diversity of all forms of education has made study at home and abroad more affordable to many students both long-term and short-term (Gordon, 2015).

Statistics showed that the number of students seeking education in foreign countries is increasing year by year, and it is predicted to rise up to 5.5 million by 2020 (Bhom et al., 2004). According to OECD report (2013), the number of student mobility rises from 1.3 million in 1990 to nearly 4.3 million in 2011, the number of Asian student was accounted for $53 \%$ of all students studying abroad worldwide, the predominantly English speaking countries such as U.S, U. K, Canada, and Australia were chosen by the majority of Asia students. However, their chosen destination is changing recently, the dominant of English speaking countries such as U.S, U.K, Germany, France, Canada is declining in attracting international students. Instead, the dominance of other English speaking destination countries with lower tuition fees and living costs is getting more international students' selection (Do, Pham, 2016). It is forecasted that international students will be changed more intraregional mobility (Brooks \& Waters, 2011) especially at prestigious institutions (UNESCO, 2015; 
OECD, 2014). This trend is explained as the growing of regional integration and internationalization processes, and the harmonization initiatives at regional higher education (Woldegiorgis et al., 2015)

In the wave of student mobility in Asia, the number of Vietnamese seek for study abroad has increased every school year, it was estimated that more than one hundred thousand even they are not accurately recorded (Ministry of Foreign Affairs of Vietnam, 2012). According to statistics of UNESCO (2014), Vietnam is one of the top ten countries of origin of mobile students (UNESCO Institute of Statistics, 2014). The chosen study destinations of Vietnamese students is very diverse, U.S and Australia have been the top-ranked destinations of many more Vietnamese students for several years even though it is perceived as being more expensive among others. However, this phenomenon recently tends to go to regional destinations. The ICEF Monitor (2014) data has indicated that in 2013 there are about 34\% of total Vietnamese study abroad enroll to study in China, Japan, Singapore, Taiwan and other regional countries which has increased in comparing to previous years.

Motivation can be defined as the want that causes someone doing something, and it "is the study of why people think and behave as they do" (Graham \& Weiner, 1996, p63). Motivation causes of the results of someone's behavior and action. The motivations of international students have pushed them going out of their country and pulled them incoming to another country for different purposes. Many seek to obtain a well-recognized qualification to be able to secure their job or getting promotion (Ming, 2010), some others want to explore and develop their cosmopolitan experiences (Hamad \& Suzanne, 2016) but others want to acquire specific skills or gaining intercultural skills and values from other cultures (Brux \& Fry, 2010; Arambewela, 2012; Bokareva, 2014; Macready \& Tucker, 2011; Lewis, 2016). Specifically, Miller and Randy (2012) pointed out that study abroad is considered as a chance for more learners' future success, especially in getting experiences in integration and "hands on" career development, it is realized as a chance to enhance student language and cultural knowledge acquisition (Salyers et al., 2015).

Laddawan Jianvittayakit (2012) analyzed and categorized the motivation factors of international students into two groups, the group of push factors such as the desire to gain educational experience, seek the opportunity to increase knowledge and self-development, the wish to travel and have opportunity to interact with local people, desire to learn foreign language, and the wish to have better career opportunity, and the pull factors are mentioned including country attributes and university attributes. Although there is no classification in term of push and pull factor, Woldegiorgis and colleagues (2015) concluded in their paper that, the student's motivations to look for study intraregional education derives from the lack of available courses at their home country, the availability of scholarship from the host countries, and the possibility of a better life in other countries. Other personal expectations such as career opportunities, job opportunities and flexible entry requirements also facilitate students study abroad.

Anderson and Lawton (2015) grouped the motivation of international students into four dimensions namely world enlightenment, personal growth, career development, and 
entertainment. According to the researchers, motivation links to the choice of program destination and to the living arrangement, their results showed that students with stronger entertainment motivations are likely to choose less challenging destinations than those motivated to learn about the world or to seek personal growth, and these students like to have deeply immerse into the indigenous culture than others. Personal growth consists of different elements, among these, English acquisition is considered as a factor influenced Asian students' choice to study abroad (Yau, 2012; Tarry, 2008; OECD, 2014). The insufficient institutions in higher education have contributed to encourage students look for international education too (Tran Le Huu Nghia, 2015; Nafari et al, 2017).

Safakli (2015) examined and found out the factor of experiencing another student life in another country with another culture, and the expected possibilities of future work have motivated foreign students to study in European university. The study revealed that the factors of crime, education level and the culture of home country also influence international students' selection of the host country.

Although study abroad is conveniently accessed to international students nowadays, they have to struggle with many difficulties in the host country. These difficulties are named as language, financial difficulties, climate, experience cultural shock with different values, social inclusion, care, etc (Anh Le, 2014; Hamad \& Suzanne, 2016; Anjalin et al., 2017). However, Zhou (2015) found out that foreign students still move on and overcome their encountered obstacles due to intrinsic interest in deepen their knowledge about specific major, the valuation of an earned degree, and the consideration of high emotional and social cost of the course in another country.

The positive impacts brought by international education have well researched and documented through different studies. It is proven that study abroad not only brings benefits to students themselves but also to the host countries (Altbach \& Knight, 2007; Mpinganjira, 2009; Brux \& Fry, 2010; OECD, 2013; Woldegiorgis et al, 2015), for instance, the additional country's annual revenues, cultural diversity, academic exchange, country's assertiveness, potentials for quality improvement, attracting talented minds from other countries.

In consideration of study abroad benefits and its new trend in the context of integration, international education has become an ever more important part in the entire education sector globally. International students and their motivations to look for study abroad have affected on educational practices such as curriculum, teaching and learning quality, programs, educational policies, and human resources like the quality of labor, incoming and outgoing of talented ones. For these reasons, many studies have conducted to investigate this phenomenon, however, the information relates to the motivations of students who come from developing country to another developing country to pursue their graduate degree within region is still insufficient, so it needs to be continued investigated not only to accommodate student's developmental needs but also add information to improve the quality of higher education in developing country and Vietnam in particular, and expand our knowledge about international education in the context of regional integration.

In light of this trend, it comes to the question "what domestic and external factors motivates 
Vietnamese look for study abroad?" To address this questions, this paper investigates the motivations of Vietnamese graduate students (VNGSs) to study in the Philippines, specifically, this paper seeks to answer the following questions: (1) What is the demographic profile of the VNGSs in the Philippines in terms of age, gender, type of university where VNGSs are enrolled, and graduate degree being pursued?; (2) What motivates VNGSs seek for study abroad? and (3) what factors motivate VNGSs choose the Philippines for their study? (4) What implications can be drawn from the study?

The researchers believe that understanding VNGSs motivations will provide practical insights to $\mathrm{VN}$ educators and policy makers, specifically to $\mathrm{VN}$ higher education and its institutions in offering competitive and productive training programs, and setting marketing strategies to take the advance of international education for effective integration.

\section{Research Methodology}

The basic methodology of this study is descriptive research. This study used mixed method so that, each drew on the strengths of the other (Creswell, 2009). It combined two data gathering methods: (1) survey by distributing questionnaire to 56 respondents (VNGSs) and (2) semi-structured interviews with 10 key informants. The procedure to gather data began with selection of motivational factors, the researchers read different studies to list down factors motivate international students look for study abroad. They rearranged these factors base on personal and external motivations, then shows to ten (10) key informants thru email. Each of key informants was scheduled to discuss about the real factors affect to VNGSs at their community, inapplicable factors were removed and others were added after getting their feedback. The researchers revised the questionnaire which was validated again by these informants before distributing to the respondents.

\subsection{Respondents of the Study}

Respondents of the study were selected by convenient sampling since the population of VNGSs is spread out to different provinces, island groups of the Philippines. It was decided that the VNGSs who are studying in Metro Manila at University of the Philippines (UP), De La Salle University (DLSU), University of Saint Tomas (UST), Philippines Women University (PWU), Asia Social Institute (ASI) and Adamson University with a total number of 56 were the subjects of the study.

Key informants for semi-structured interview were selected according to their assigned task as representatives of Vietnamese community at each university, two representatives at each university were chosen. However, Adamson University has only one VNGSs while PWU's representative was on vacation in their home country, so ten (10) key informants were selected to be subject for semi-structured interview. 


\subsection{Treatment of Data}

After gathering data, the researchers encoded and classified them into categories. The profile of the respondents is presented through distribution tables of frequencies, and percentage. In the second part of the questionnaire, the researchers used frequencies, percentage, and the Likert scale to determine motivating factors affect VNGSs' seeking for study abroad and motivating factors in choosing Philippines as their destination. Four levels were given to determine respondents' attitudes to each item which ranges from 1 'Strongly not motivated' to 4 "Strongly motivated", specifically, the mean score value is interpreted as follow: Mean < 1.75: Strongly not motivated; $1.75-2.50$ : Not motivated; $2.51-3.26$ : Motivated and, $3.27-$ 4: Strongly motivated. With gathered information and analyzed data, the researcher used semi-structured interviews to get key informants information and explanation about the results, meanwhile participant observation and secondary resources also were used to substantiate and deepen the explanations. They are cited step by step in accordance with each part of the study for analyzing and interpreting both quantitative and qualitative presentation.

\section{Results and Discussion}

\subsection{Profiles of the Respondents}

Table 1 presents the profiles of the respondents.

Table 1. The Profiles of the Respondents $(\mathrm{N}=56)$

\begin{tabular}{llcc}
\hline \multirow{2}{*}{ Variable } & & Frequency & Percentage \\
\hline \multirow{2}{*}{ Gender } & Female & 22 & 39.3 \\
& Male & 34 & 60.7 \\
\hline \multirow{2}{*}{ Status } & Single & 36 & 66.6 \\
& Married & 20 & 33.4 \\
\hline \multirow{4}{*}{ Age } & $25-29$ & 24 & 42.9 \\
& $30-34$ & 17 & 30.3 \\
& $35-39$ & 14 & 25 \\
\multirow{2}{*}{ Type of enrolled university } & Public & 21 & 37.5 \\
& Private & 35 & 62.5 \\
\hline
\end{tabular}

Data shows that the bulk of VNGS are in the age bracket of 25-29. The average age of the VNGSs is 31 which tells that the VNGSs in the Philippines have some work experiences after having finished an undergraduate program at the age of $22-23$. It can be observed that as the age bracket increases, there is a decrease in the frequencies. Being a Vietnamese, the key informants informed that younger VNGSs can easily make a choice for their future especially for professional growth in a foreign country because of their job engagement and expected better career, and being unmarried. At the age of 30-34 and up, most of the people have already well established careers and families. These related job status and family responsibilities have affected their choice with regards to studying abroad, live far from their 
families and possibly leave their work for a few years. This explains why there are declining numbers of VNGSs corresponding to the higher age brackets.

There are more male VNGSs compared to females, this inequality derives from the Asian culture with the influence of Confucianism doctrine, although the practice of Confucianism doctrine is no longer very much evident, in the heart of many Vietnamese, it is still affected, although unconsciously. According to the minister of Labour, Invalids, Social Affairs Pham Thi Hai Chuyen, gender inequality continues to persist in all areas and sectors, that limit women access to job and education, (VietnamNews, 2015) it explains why there is less female rather than male in this study.

There are more than half $(62.5 \%)$ of the VNGSs are enrolled in private universities, and only $37.5 \%$ are enrolled in public. The qualitative data helps to explain this difference by the following reasons: firstly, UP is the only public university with the rigorous admission policies, which is considered as the premiere university in the country, therefore, to be admitted into this school, VNGSs are required to meet very competitive and strict requirements that many of them were not able to meet. Secondly, the Philippines state policies on higher education that assigned the Commission on Higher Education (CHED) as a government body to supervise training quality. Thus, most higher education institutions' curricular programs have passed through CHED's evaluation and accreditation to be recognized. For these two reasons, the respondents have chosen the university with the program that they are qualified for but still meets their professional needs and expectation, the higher tuition fees in private institutions is not a deterrent their enrollment in private schools. This finding is consistent with Cordina and colleagues' (2013) results on the activeness of private school to develop and promote professionalization of international education.

Table 2. Graduate Degree being Pursued $(\mathrm{N}=56)$

\begin{tabular}{lcc}
\hline \multicolumn{1}{c}{ Variable } & Frequency & Percentage \\
\hline Master in Business Administration & 12 & 21.4 \\
Master of Arts in Education & 11 & 19.6 \\
Master of Science in Social Work \& Community & 10 & 17.9 \\
Development & & \\
Master of Science in Sociology & 5 & 8.9 \\
Master of Arts in Teaching English Language & 5 & 8.9 \\
Master of Arts in Theology & 3 & 5.4 \\
Master of Science in Environmental Engineering & 3 & 5.4 \\
Master of Arts in Counseling & 3 & 5.4 \\
Master of Arts in Communication & 2 & 3.5 \\
Economics & 1 & 1.8 \\
Master of Science in Medical Technology & 1 & 1.8 \\
\hline Total & $\mathbf{5 6}$ & $\mathbf{1 0 0}$ \\
\hline
\end{tabular}


Table 2 shows that most of the VNGSs enroll in the field of Social Sciences and Humanities, the majority is in Master in Business Administration (21.4\%). It can be explained by the fact that over the last 20 years, the renovation and open door policy in $\mathrm{VN}$ have created favorable conditions for the development of all non-state economic and social organizations that attracts more individuals to engage into the economy, therefore, enrolling in master of business administration, the respondents want to be capable to engage in country's potential growth.

The second biggest group is Master of Arts in Education (19.6\%) and very few (1.8\%) take up graduate courses in Economics and Medical Technology. The results of globalization have provided more opportunities and challenges in term of both quality and quantity of education. In light with this, educational involvement is seen as prosperous job to engage in, so more young ones leave the country to look for professional development in the field of education which becomes the choice of the second biggest group of the respondents.

Alongside with economic growth, drastic social development also causes other social issues such as poverty, inequality, violence, climate change, etc that requires the concerns and efforts of government, policy makers, leaders, social workers, and various sectors to promote citizens' well-being and to develop country sustainably, meanwhile, the Philippines is considered "long history of social work practice and good quality of training in social work profession" as key informant said. Thus, ten (10) respondents enroll in Social Work and Community Development who wish to take part in promoting and empowering their people.

Five respondents are enrolled in Sociology accounts for $8.9 \%$. The sharing of key informants informs that all of these students are expected to go back to their own country to teach in higher education institutions. Being fluent in English is one of the advantages of any Vietnamese, however, the level of Vietnamese's English competency is still low and Vietnam's English skills ranks behind many other Asia countries such as Malaysia, Hong Kong, Philippines, Singapore, South Korea, India (VnExpress, 2016) while Philippines is recognized globally as one of the largest English-speaking nations, this attracts five respondents $(8.9 \%)$ come to enroll in English courses.

There are only three VNGSs who are pursuing graduate courses in Environmental Engineering and three in Counseling (5.4\%). It reflects that, there are not many Vietnamese pursue these graduate programs in abroad, specifically in the Philippines, this data aligns with the findings of Shangton Chang, et al., (2016) who found out that IT and engineering students statistically considered less mobile than in many other disciplines (p. 300). Another three respondents enrolled in Theology who are Catholic (5.4\%) even if the major religion in Vietnam is Buddhism. These respondents believe that they would serve their parishes better in doing religious work with gained competency from Philippines graduate education.

\subsection{VNGS's Motivational Factors to Look for Study Abroad}

The factors influence VNGS look for study abroad are diverse and is presented in Table 3. 
Table 3. The factors motivate VNGS study abroad

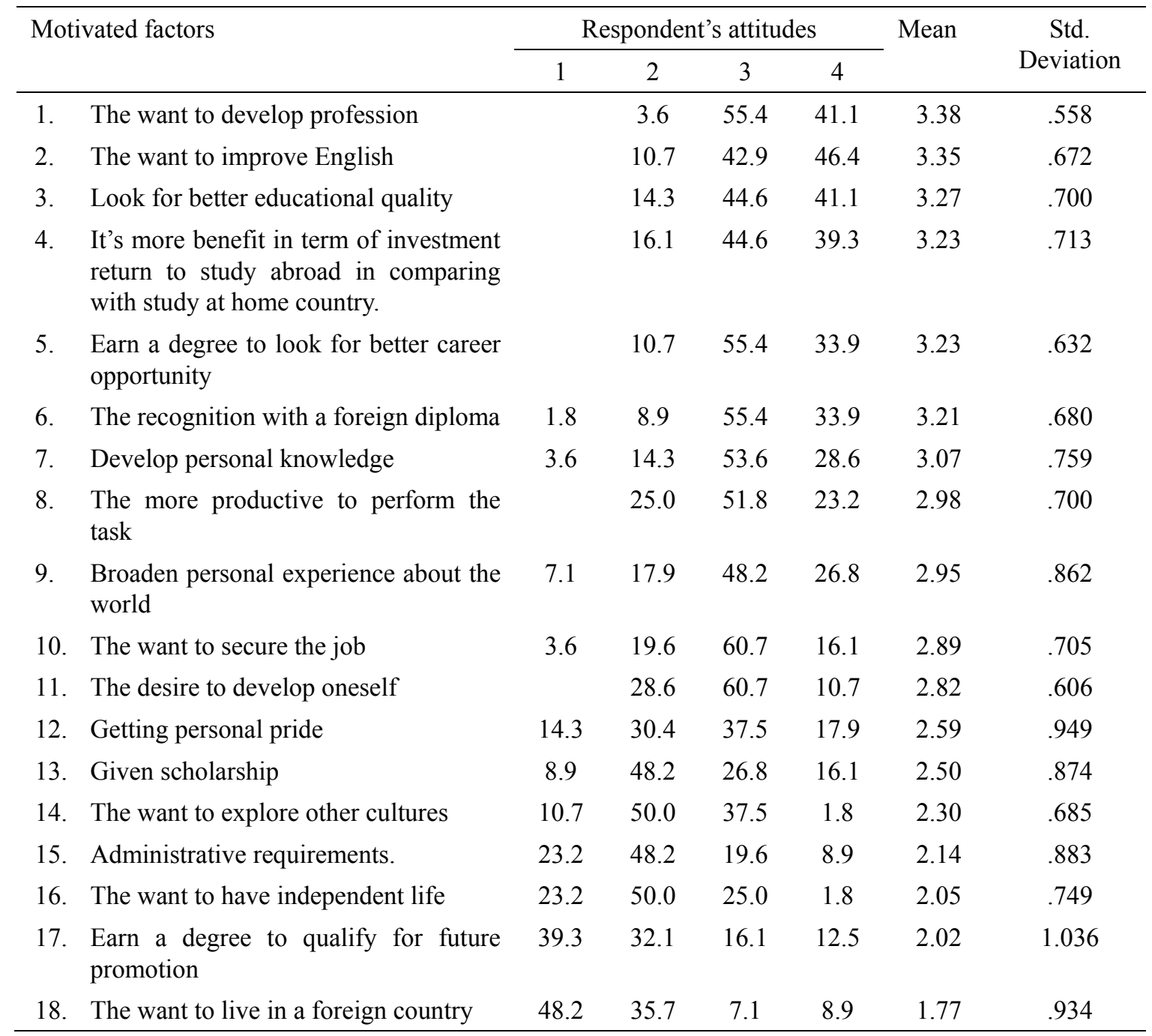

The factors of professional development (mean $=3.38)$ and improving English skills (mean = 3.35) strongly motivated VNGSs look for study abroad while the want to live in a foreign country $(M=1.77)$ is not significant to the respondents. It is noted that integration demands for new competencies that pushes people's life-long learning to respond to the new requirements of workforce. Since English has been chosen as an international language, being fluent in English is realized as an advanced mean to any Vietnamese. This is the reason why the respondents decided to immerse themselves in a foreign country to experience language-learning environment. The mean score of two factors are closely equal and it is explained and confirmed thru the quality data, "I can study at international schools in Vietnam, however, it is still Vietnam, so I decided to go out of the country where I can both master my profession and my English." This result confirms for previous findings conducted by Tarry (2008) and Yau (2012) on the need of English acquisition of Asian students, and rejects Woldegiorgis and colleagues' (2015) findings who blamed that lacking of available courses had influenced students choice to look for intraregional education. 
Educational quality is another important concern of the respondents that pulls them out to study abroad (mean $=3.27$ ). Qualitative data was collected and it revealed that VNGSs considered the problematic training of Vietnam higher education when it is isolated from international currents of knowledge and differs from other Southeast Asian countries, the training of higher education institutions doesn't closely link to scientific research, businesses, industries and employers (Nha \& Tu, 2015). Although the Philippines is not as good education quality as other developed countries, they hoped that education from this foreign country would be better than domestic education. This reason associated with VNGSs' perception on more returned benefits to study abroad $(\mathrm{M}=3.23)$ both in term of profession and skills acquisitions.

The factor of looking for better career opportunity after getting a degree $(\mathrm{M}=3.23)$ and the recognition with a foreign diploma $(\mathrm{M}=3.21)$ also contributed to VNGSs' choice to study abroad too. The wish to expand personal knowledge $(\mathrm{M}=3.07)$, to broaden personal experience about the world $(M=2.95)$, and the desire to develop oneself $(M=2.82)$ also contributes to VNGSs study abroad decision.

Knowledge and skills acquisition parallel with one's ability in doing his task, so continue to study at graduate level is expected to help VNGSs become more efficient to accomplish their task at particular field $(M=2.98)$. Other factors namely the want to secure the job $(M=2.89)$, and getting personal pride $(\mathrm{M}=2.59)$ also motivated them for further study which derives from personal desire to be acknowledged by others and supplement for their job status. These two factors are further explained by the key informants "there are lots of bachelor holders, so earning a graduate degree in a foreign country will give us more advanced chance to have better career and proudly recognized by others."

Receiving scholarship $(\mathrm{M}=2.50)$ and administrative requirement $(\mathrm{M}=2.14)$ are perceived not motivated VNGSs go to study abroad even though these are contributed factors to attract some VNGSs. The want to explore other culture $(\mathrm{M}=2.30)$, to have independent life $(\mathrm{M}=$ $2.05)$, and to live in foreign country $(\mathrm{M}=1.77)$ are not motivated factors to VNGSs as well, the key informant added information, "Although many of us still depend on our family's financial supports, we are mature enough to decide for our life and our career". They shared "no place is heaven, some want to escape from VN but still have many others aware that wherever we live, we have to work. So if you earn qualified degree with appropriate competencies, it will be more convenient (well-paid job) to live and work in your home country." The factor of earning a degree to qualify for future promotion is found not motivated VNGSs look for study abroad with mean score is 2.02 .

\subsection{Factors Motivate VNGSs Choose the Philippines.}

VNGSs choose to study in the Philippines for different purposes and it attracts their coming for the following reasons. 
Table 4. Major motivating factors influenced VNGSs' decision to study in the Philippines

\begin{tabular}{|c|c|c|c|c|c|c|}
\hline \multirow[t]{2}{*}{ Motivating factors } & \multicolumn{4}{|c|}{ Respondent's attitudes } & \multirow[t]{2}{*}{ Mean } & \multirow{2}{*}{$\begin{array}{c}\text { Std. } \\
\text { Deviation }\end{array}$} \\
\hline & 1 & 2 & 3 & 4 & & \\
\hline 1. Affordable tuition fees & & 1.8 & 53.6 & 44.6 & 3.43 & 5.35 \\
\hline 2. Lower of living costs & & 7.1 & 42.9 & 50.0 & 3.43 & .628 \\
\hline 3. English speaking environment & & 12.5 & 41.1 & 46.4 & 3.34 & .695 \\
\hline 4. Easy for travelling & & 8.9 & 48.2 & 42.9 & 3.34 & 6.40 \\
\hline 5. The closeness of home country & & 7.1 & 58.9 & 33.9 & 3.27 & .587 \\
\hline 6. The climate similarities & & 30.4 & 60.7 & 8.9 & 2.79 & .594 \\
\hline 7. Religion connection & 3.6 & 41.1 & 46.4 & 8.9 & 2.61 & .705 \\
\hline 8. Quality of Philippines education & 5.4 & 39.3 & 53.6 & 1.8 & 2.52 & .632 \\
\hline 9. Safety & 3.6 & 46.4 & 46.4 & 3.6 & 2.50 & .632 \\
\hline $\begin{array}{l}\text { 10. Recommendation } \\
\text { administrators }\end{array}$ & 8.9 & 57.1 & 26.8 & 7.1 & 2.32 & .741 \\
\hline 11. Family arrangement & 21.4 & 53.6 & 10.7 & 14.3 & 2.18 & .936 \\
\hline 12. Tourist attraction & 17.9 & 57.1 & 25.0 & & 2.07 & .657 \\
\hline 13. Recommendation from other students & 26.8 & 51.8 & 8.9 & 12.5 & 2.07 & .931 \\
\hline
\end{tabular}

The data shows that, lower living costs $(M=3.43)$ and cheaper study expenses $(M=3.43)$ in the Philippines are the most important conditions for VNGSs being motivated. The qualitative data explained that even though not all of them are fully self-funded students, some of them have partial subsidy from their institutions, others have loan for their study, all always concern about the amount they spend on study with the relevance of gained benefits from this exposure in comparing with other countries. This information aligns with the report of the Ministry of Foreign Affairs on the phenomena of study abroad which emphasized that self-funded study has become more common of VN students (2012) and as its consequence, students always put their special efforts concentrate on countries that they can afford (Nelly, Karen, 2014).

Communication skills acquisition $(\mathrm{M}=3.34)$ and traveled convenience $(\mathrm{M}=3.34)$ strongly associated with VNGSs' decision come to the Philippines where is known of its top universities use English as a medium instruction. The closeness of the Philippines to Vietnam also strongly pulled VNGSs come to pursue their study in this neighboring country $(\mathrm{M}=$ 3.27). The key informants explained "It will be more benefits in global economy when we can both enhance our profession and being fluent in English with greater affordable expenses in the Philippines... We are Asian countries, it is easy to go and come back home by Cebu pacific airlines with cheap fare, the weather is not much different, living cost is not much higher, many things are similar to VN." This explained why the climate similarities $(\mathrm{M}=2.79)$ contributed to VNGSs' motivation to study in the Philippines $(\mathrm{M}=2.79)$. The factor of religious connection also influenced respondents' decision to come to the Philippines $(\mathrm{M}=$ 2.61) and it is informed by the key informants "Most of us we are Catholic, some are 
laypersons, so we find it easier to look for a place/ convent to stay in and we feel comfortable to live and study in the Christian country... " The quality of Philippines education attracted VNGSs $(\mathrm{M}=2.52)$ where they expected to access better education.

The factor of safety $(M=2.50)$, recommendation from administrators $(M=2.32)$, and family arrangement $(\mathrm{M}=2.18)$ did not influence VNGSs choice. With the same mean score $(\mathrm{M}=$ 2.07) for the factor of tourist attraction and recommendation from other students also did not contribute to VNGSs decision to select Philippines as their study destination. This result contrasts with the previous study conducted by Mayers (2013) who emphasized that students are most likely to attend institution that a friend of a family member has attended.

\section{Conclusion and Implementations of the Study}

"Knowledge era" requires individuals continue to enhance and develop themselves to be able to catch up with the rapid growth in all the aspects of social life. This situation pushes VNGSs go out of their home country to look for study abroad where they expected to gain greater skills and knowledge. Although Philippines is a neighbored and developing country, it is chosen as study destination for the respondents due to its affordable tuition fees in parallel with lower living costs, the advance of English speaking environment, the eco-social familiarities and the convenience brought by the closeness. Although the participants are reflective of the motivations of VNGSs studying in selected universities, this study cannot be generalized to all students who come from VN to pursue graduate education in the Philippines, however, from these findings, the following implications can be drawn:

International integration opens up more chance for individuals, more young ones continue to pursue their further study in abroad especially at graduate level, more costs and gained benefits will be brought from this mobility. In light with this, Vietnam higher education, especially graduate education needs to review it curriculum and importantly to assure its training quality, to offer different courses in order to respond to professional development and life-long learning of his people and other international students within the region.

Study abroad not only benefits to students themselves but also brings many advanced opportunities and benefits to the host country. $\mathrm{VN}$ is a country with many available resources in term of geography, politics, living standards, weather, and convenient travel. The results affirms that international language is a unique factor affects one's choice therefore, creating favorable academic programs by using English as a medium of instruction at VN graduate will help not only VNGSs but also VN higher education effectively engages in international education and accommodate international students, especially students come from neighboring countries find it more favorable to choose $\mathrm{VN}$ as their academic destination.

Our world becomes increasingly internationalized and student mobility is paralleled with this process, this is not a new phenomena in education, however, the mobility tends to be more intraregional and self-funded by students, so the $\mathrm{VN}$ universities itself needs to take this opportunity to promote themselves and partnership with other members to bring in and bring out his graduate students thru international fieldtrip, exchange students that properly will respond to VNGSs need to enhance their competency with appropriate school fees. 
It is hoped that the findings will provide information to administrators and educators to conceptualize better strategies related to quality, costs, and the use of English in graduate education to optimize the advance of international education which recently spreads in all the levels of VN education. This study is the first step to examine the motivations of VNGSs to study in the Philippines, for broader understanding about VNGSs in the Philippines and VNGSs' experiences in Philippines graduate programs or its curriculum, further studies need to be conducted.

\section{References}

Anh Le. (2014). Vietnamese International Student Repatriates: An Exploratory Study. A Dissertation for the degree of Doctor of Philosophy. University of Nebraska.

Anderson, P. H., Lawton, L., \& Hubbard, A. (2015). Student Motivation to Study Abroad \& Their Intercultural Development.Management Faculties Publications, 23.

Altbach, P. G., \& Knight, J. (2007). The Internationalization of Higher Education: Motivations and Realities. Journal of Studies in International Education, 11(3\&4), 290-305. http://dx.doi.org/10.1177/1028315307303542

Anjalin, U., Mazumdar, A., \& Whiteside, E. (2017). Asian Students' Experience of Culture Shock and Coping Strategies.Journal of Education and Social Development, 1(1), 7-13. http://dx.doi.org/10.5281/zenodo.834930

Arthur, N., \& Popadiuk, N. (2015). International Students' Wellbeing, Relationships and Quality of Life. In Marcus A. Henning, Christian Krageloh, Glenis Wong-Toi (Ed). StudentMotivation and Quality of Life in Higher Education. By Routledge NY.

Arambewela, R. (2012). Student Experience in the Globalized Higher Education Market: Challenges and Research Imperatives. In Felix Maringe, NikcFoskett (Ed). Globalization and Internationalization in Higher Education: Theoretical, Strategic and Management Perspectives. A Bloomsbury Company, NY.

Bokareva, M. (2014). Social Causes of Russian Students' Motivation to Study Abroad.Procedia Social and Behavioral Sciences, 127, 124-128.

Brux, M.J., \& Fry, B. (2010). Multicultural Students in Study Abroad: Their Interests, Their Issues, and Their Constraints. Journal of Studies in International Education, 14(5), 508-527.

Brooks, R., \&Waters, J. (2011). Student Mobility, Migration and the Internationalization of Higher Education. Published by Palgrave Macmillan.

Böhm, A., Follari, M., Hewett, A., Jones, S., Kemp, N., Meares, D., Pearce, D., \& Cauter, K. V. (2004). Vision 2020: Forecasting International Student Mobility. A UK Perspective.By British Council, IDP Education Australia and Universities UK.

Codina, B., Nicolás, J., López, L., \&Hernán, R. (2013). The Importance of Student Mobility, Academic Exchange and Internationalization of Higher Education for College Students in a Globalized World: The Mexican and Latin American Case. International Journal of Good 
Conscience, 8(2), 48-63.

Commission on Higher Education (CHED). Memorandum Order (CMO). Series of 2007.No.53. Policies and Standards for Graduate Programs in Education for Teachers and other Education Professionals.

Creswell, J. W. (2009). Research Design: Qualitative, Quantitative, and Mixed Methods Approaches. Thousand Oaks. Sage Publications.

Do, T. T., \&Pham, N. D. (2016). Challenges of Students Mobility in Southeast Asia.Journal of International Higher Education, 84, 24-26.https://doi.org/10.6017/ihe.2016.84.9118

Gordon, E. S. (2015). International Teaching and Learning at Universities: Achieving Equilibrium with Local Culture and Pedagogy. In Gordon, E, S and Jane Vinther (Eds).Published by Palgrave Macmillan, NY.

Graham, S., \&Weiner, B. (1996). Theories and Principles of Motivation. University of California.

Hamad Alghamdi, Suzanne Otte. (2016). The Challenges and Benefits of Study Abroad.International Journal of Humanities and Social Science, 6(5).

ICEF Monitor. (2014).Number of Vietnamese Abroad up 15\% in 2013. Retrieved from http://monitor.icef.com/2014/11/number-vietnamese-students-abroad-15-2013/

Knight, J. (2012). Student Mobility and Internationalization: Trends and Tribulations. Research in Comparative and International Education, 7(1), 20-33.

Lewis, W. (2016). Study Abroad Influencing Factors: An Investigation of Socio-Economic Status, Social, Cultural, and Personal Factors. The Undergraduate Research Journalat the University of Northern Colorado, 5(3).

Laddawan Jianvittayakit. (2012). Motivation Factors of International Student in Choosing a Foreign University. Interdisciplinary Studies Journal, 12(2), 172-189. http://dx.doi.org/10.6007/IJARPED/v4-i4/1863

Mpinganjira, M. (2009).Comparative Analysis of Factors Influencing the Decision to Study Abroad.African Journal of Business Management, 3(8), 358-365. http://dx.doi.org/10.5897/AJBM09.117

Ministry of Foreign Affairs of Vietnam. (2012). Review of Vietnamese Migration Abroad. Consular Department. Retrieved fromhttps://eeas.europa.eu/delegations/vietnam/documents/eu_vietnam/vn_migration_abroad _en.pdf

Miller, R. S. (2012). Understanding the Motivation of Vietnamese International Students and their Higher Education Experiences in the United States. Dissertation for the degree of Doctor of Philosophy in Education. University of North Texas.

Ming, J. S. K. (2010). Institutional Factors Influencing Students' College Choice Decision in 
Malaysia: A Conceptual Framework. International Journal of Business and Social Science, 1(3), 53-58.

Nelly P. Stromquist, Karen Monkman (2014). Globalization and Education: Integration and Contestation across Cultures. Published by Monkman, Rowman and Littlefield Education.Second edition.United of America.

Nafari, J., Arab, A., \& Ghaffari, S. (2017). Through the Looking Glass: Analysis of Factors Influencing Iranian Student's Study Abroad Motivations and Destination Choice. SAGE Journals. http://dx.doi.org/10.1177/2158244017716711.

OECD (2012). Education at a Glance. OECD publishing, Paris.

OECD (2014). Indicator C4: Who studies abroad and where? Education at a Glance. OECD publishing, Paris.

OECD (2013). Education Indicators in Focus. Published by OECD.

Salyers, V., Carston, S. V., Dean, Y., \&London, C. (2015). Exploring the Motivations, Expectations, and Experiences of Students Who Study in Global Settings. Journal of International Students, 5(4), 368-382.

Safakli, V. O., \&Ihemeje, O.O. Obed. (2015). Motivation of Students Studying Abroad: Case of Foreign Students in European University of Lefke. International Journal of Academic Research in Progressive Education and Development, 4(4), 1-10. http://dx.doi.org/10.6007/IJARPED/v4-i4/1863

Shanton Chang, Martina von Imhoff, Rikke Ilona Ustrup (2016). Engineering and Information Technology: Challenges and Opportunities for Exchange Studies. In Vellians, Donna M, Coleman - George (Ed). Handbook of research on study abroad programs and outbound mobility. Published by IGI Global.

Tran Le HuuNghia (2015). Factors influencing prospective international students' motivation for overseas study and selection of host countries and institutions: The case of Vietnamese students. Paper presented at the $26^{\text {th }}$ ISANA International Education Conference.

Tarry, F. (2008).Thai Students and their Reasons for Choosing to Study in United Kingdom Universities.Published thesis for the degree of Doctor of Education.University of Bath.

Tucker, C., \& Macready, C. (2011). Who Goes Where and Why? Global Education Research Reports, Report 5, Institute of International Education, New York.

UNESCO. (2015). Global flow of tertiary-level students. Retrieved from http://www.uis.unesco.org/Education/Pages/international-student-flow-viz.aspx.

Vietnam News. (2015). Gender Gap Closer, Inequality Remains. Retrieved from http://vietnamnews.vn/society/health/236627/gender-gap-closes-inequality-remains.html\#82r 7EedYgCOPURpH.97

VnExpress. (2016). Vietnam's Skills rank seventh in Asia. Retrieved from 


\section{Macrothink}

International Research in Education

ISSN 2327-5499

2018, Vol. 6, No. 1

http://e.vnexpress.net/news/news/vietnam-s-english-skills-rank-seventh-in-asia-3499409.html

Woldegiorgis, E. T., \& Doevenspeck, M. (2015). Current Trends, Challenges and Prospects of Student Mobility in the African Higher Education Landscape. International Journal of Higher Education, 4(2), 105-115. http://dx.doi.org/10.5430/ijhe.v4n2p105

Zhou, J. (2015). International Students' Motivation to Pursue and Complete a Ph.D. in the U.S.The International Journal of Higher Education Research, 69(5), 719-733. http://dx.doi.org/10.1007/s10734-014-9802-5

Yau TSAI. (2012). The Effects of Intercultural Learning on English Learning Motivation among Students Studying Abroad. Journal of New Horizons in Education, 60(1), 23-34.

\section{Copyright Disclaimer}

Copyright reserved by the authors.

This article is an open-access article distributed under the terms and conditions of the CreativeCommons Attribution license (http://creativecommons.org/licenses/by/3.0/). 